\title{
UKRAINIAN SPORTS JARGON AS A LINGUISTIC PHENOMENON
}

\author{
Karpets L. A., Kovalenko J. N.
}

\section{INTRODUCTION}

An important and interesting debate issue for many years now has been the study of the richness of spoken natural language. The study of "living" language becomes a priority in the scientific works of linguists, gaining more and more new positions. The object of such works is, in particular, the once-taboos of various linguistic phenomena, which have been given different names in linguistics - social dialect, argo, jargon, slang, kent, etc.

The process of study of these phenomena is quite complex and contradictory, there is no unified and generally accepted explanation of their nature and some common methods of their study are not produced. However, the traditional study of language phenomena at the level of "system" and "norm" (which is one of the urgent tasks of modern linguistics) is impossible without taking into account the features of these so-called "peripheral" layers of language.

The study of such phenomena, their development and consequences was addressed, in particular, by representatives of the sociological direction of French linguistics (especially its conductor A. Meié), the Prague Linguistic School (V. Mathesius, B. Gavranek, J. Wachek), German scholars of the Leipzig Linguistic Linguistics Frings, Russian School (O. Shakhmatov, I. Baudouin de Courtenay, E. Polivanov). It is their undoubted theoretical justification for the close connection of language with social processes.

A small number of scientific works devoted to these problems (such as, in particular, a thorough study of modern domestic scientists O. Gorbach, J. Dzendzelovsky, Y. Shevelyov, L. Masenko, L. Stavitskaya, etc.) - this is only a description of the main directions, definition of strategic tasks and priorities. Some issues remain debatable and require deep and thorough consideration.

Today, almost all socio-occupational groups have their own jargon nomination methods. It may be said about computer jargon, jargon of drivers, hairdressers, accountants, doctors, and more. But not all jargonisms are accessible to the general public, most of them are only understood by some professional community, and the jargon itself meets the needs of the speakers in different ways. Among modern social dialects, sports jargon is one of the most common, which can be explained by the mass and 
prevalence of various kinds of sport and sports activities among the population.

The modern sports community with the appropriate educational and professional level, which constantly cares about its sports image, readily serves the youth and other jargon, but necessarily creates its own linguistic world, dominated by names for the designation of realities and concepts of sports, different human qualities. appeared in various actions, exercises, etc.

It should be noted that the sports microsocium, as a subject and object of jargon formation, has its own internal structure, which has been formed over the years.

The popularity and mass sports, the declaration of the results of competitions in the media, other non-linguistic factors greatly contribute to the penetration of sports nomenclature into broad areas of communication, which in turn form a specific microsystem of the Ukrainian language.

Sports nomination is characterized by a number of peculiar features. First, it mainly uses traditional national techniques and nomination methods. Secondly, the most active, the most important, the most significant sports phenomena(such as the names of sports, sports equipment, various types of exercises, names of processes and actions, sports establishments, awards, etc.) fall in to the range of interests. Thirdly, in comparis on to other "professional" nomens, sports units (with a few exceptions) do not cause difficulty in perception, understanding and presentation, as they have a high prevalence of native speakers and for the most part transparent motivation. It is worth noting that sports jargon is the most moving component that undergoes noticeable changes even within a small period of time. Moreover, such changes do not concern the individual elements and properties, but affect the fundamentals of the phenomenon itself. It is safe to say that, compared to the original stages of existence, modern jargon has almost completely changed its speaker, functions, and degree of distribution. Factors affecting the jargon presence and the spread of it have also greatly changed.

By using our own observations and researches of other scholars, we understand jargon as a particular non-codified component of the language of a certain social, professional or age group, existing and functioning in close relationship with other codified and non-codified, commonly used and interpreted counterfactuals. Accordingly, jargonim is an element of such jargon (phonetic, lexical, word-forming, semantic, syntactic), and jargonism is the jargonim used in other sublanguage (in fiction, media, spoken language, etc. $)^{1}$.

1 Карпець Л. А. Український спортивний жаргон: структурно-семантичний аспект : автореф. дис. ... канд. філол. наук : 10.02.01, Харків, 2006. С. 7. 


\section{Emerging causes, features of distribution and usage of jargonims in the athlete's language}

In Ukrainian society, physical education has always occupied a leading position. The physical culture sector itself is distinguished by its dynamics: new kinds of sport are constantly emerging, traditional ones are being improved, and a wide range of citizens (and not just young people) are involved in sports. Getting into the environment of athletes, the newcomer one way or another, whether he wants or not, is included in a certain microgroup, with its rules, mechanism of relationships, etc. This process is not only characteristic of sports communities, but also reflects objective processes in society in general, since "any society cannot inherently be socially homogeneous; it is divided into social, corporate groups with its sub-language, which, on the one hand, defies the literary standard, and, on the other, produces its own self-sufficient linguistic micro-world, indifferent to the standards and to other social-linguistic groups. In such groups, where oral communication takes place, intimate-familial, trusting relationships prevail between its members and their own intense life of language and its evolution takes place"2. Although, as the observations show, it (sublanguage) contacts with its kind forms, borrows from them, or, conversely, becomes a source of replenishment of other sublanguages. Apparently, the "indifference" or more precisely the singularity of such a subject can be said as a relative phenomenon.

In order to have a complete picture of the development of sports jargon in Ukraine, we conducted a series of studies, analyzing, in particular, the interrelations of some factors regarding the degree of occurrence, spread (non-proliferation) of jargon phenomena. Notable ones include:

1) jargon and age;

2) jargon and education;

3) jargon and family (extra-family) sphere;

4) jargon and type of settlement;

5) team and individual sports.

The survey was attended by 1635 respondents aged eight to seventy years (to trace the specifics of the jargon's functioning depending on the respondents' age characteristics).

The analysis of the materials of the questionnaires showed that the most frequently used sports jargon is youth (see Table 1). Such results are explained by the individual characteristics of speakers of different generations. As we can see, the largest percentage of people using sports

2 Ставицька Л. Функціонування жаргонної лексики в сучасній українській уснорозмовній мові Вісник Харківського університету. Вип. 491. Серія «Філологія». Харків : ХНУ, 2000. С. 295. 
jargon units are people aged 16-22. We consider this not accidental. For the most part, these are students and student-athletes who, quite often during training, meetings, competitions, are in a closed "sports" environment.

Table 1

Jargon and Age

\begin{tabular}{|c|c|c|c|}
\hline № & Age group & $\begin{array}{c}\text { Quantity } \\
\text { of respondents }\end{array}$ & $\begin{array}{c}\text { Percentage of the } \\
\text { number of respondents }\end{array}$ \\
\hline 1 & 8-15 years old & 205 & $22 \%$ \\
2 & $16-22$ y ears old & 550 & $72 \%$ \\
3 & $23-35$ years old & 380 & $33 \%$ \\
4 & 36-70 years old & 500 & $18 \%$ \\
\hline
\end{tabular}

In the speech of the representatives of this age group we can clearly distinguish the obligatory types:

1) units of purely sports theme: himka 'section of sports gymnastics', devyatyna 'top corner of the football goal', var 'varnometer', etc .;

2) units of general youth (mostly student) jargon: khvist 'academic debt', stepan, pensiya 'scholarship', para 'grade two' or 'classes', etc .;

3) separate elements of other jargon (sydyuk 'CD');

4) inter-jargon units (ment, ksyva, zeleni).

There is a significant percentage of jargon users among people aged 23-35. It is mainly physical education teachers, athletes. Given that they were recently students, elements of student jargon are still available in their arsenal (are still not forgotten), albeit in a much smaller number; units for the designation of sports realities prevail. Coaches, when communicating with their pupils, often use sports jargon for accessibility, convenience, perhaps even for "rapprochement". They are ranked second among the jargon users.

The third group is mainly pupils and students of sports schools aged 815 years. In their language, the following jargons are common: fizra 'physical culture', hynkuvannya 'break in to the column', mauhli 'physical education teacher', fizbursa 'school of physical culture' and others. A large number of students attend various sports sections, have sports idols and more. Against this background, we fix a variety of jargons: tr' osha 'training', himka 'gymnastics', Sheva 'a football player Andrey Shevchenko'.

The older generation (fourth age group), in comparison to others, use sports jargon less: in most cases the use of jargon is characteristic of the language of trainers (at training sessions), athletes, fans, sometimes they use material from the media: hirchychnyk 'yellow card which fixes the referee's warning to the player' and others. 
Surveys have shown that sports-school kids sometimes use preschoolers, mostly those who have parents or older siblings who play sports. Preschoolers try to copy the speech of the elders in order to stand out from their peers, to prove their superiority and seniority, and 'to belong' in the family. They are not the creators of this jargon, but only to some extent users.

The analysis of the materials of the questionnaires leads to the conclusion that the importance of the jargon component in the speech depends on the level of education of the respondent, and possibly, is predetermined by it (see table 2).

Table 2

Jargon and Education

\begin{tabular}{|c|c|c|c|}
\hline № & Education & $\begin{array}{c}\text { Quantity } \\
\text { of respondents }\end{array}$ & Number of users \% \\
\hline 1 & Higher & 250 & $25 \%$ \\
2 & Incomplete higher & 250 & $65 \%$ \\
3 & Secondary special & 250 & $38 \%$ \\
4 & Secondary & 250 & $22 \%$ \\
5 & Pre-school & 80 & $10 \%$ \\
\hline
\end{tabular}

Comparison of the types of speech behavior by level of education shows that sports jargon is consciously served mainly by informants with incomplete higher education and secondary specialized education, which is obviously due to some peculiarities.

First, the origin of pupil and student sports jargon has been influenced, perhaps, by relative autonomy (albeit situational), by the closed environment - almost all students live in boarding schools and are in the same educational institution. Here, in the aggregate, the names of the various jargon - from the general student to the own sports: kayuta 'bedroom', spetsukha 'specialty of the chosen sport', verblyud 'in skiing uneven hilly track' and more. Secondly, quite often these respondents are in the same environment, communicating with each other in competitions, trainings.

The extent of sports jargon is also influenced by the sociopsychological aspects of athletes' language activity. The psychological dominance of the social and linguistic life of sports jargon speakers is related to the nature of their life. In sports, people learn about the world primarily through a variety of motor actions, through which they improve their athletic skills. According to psychologists, athletes dominate "thinking in motion" in connection with such activities. The real life of a person in sports testifies to the fact that exercise, training, competition are not only strenuous physical work, but also no less strenuous intellectual activity, which forms in sportsmen "various intellectual skills and mental skills, most closely related on the one hand, 
with the subject and content of sports activities, and on the other, with social models of life struggle for their place in society". ${ }^{3}$

Of course, a person of sports spends a lot of time not at the library, visiting museums, theaters, etc., but on the training grounds. According to observations, athletes use language information from various sources. And to analyze their language awareness, we conducted a series of observations and questionnaires. On the basis of such works we can draw some conclusions:

- the athlete receives the largest percentage of language information from the coach, teammates, senior teammates; coaches, trying to make information accessible, use or create the right names to indicate certain exercises, actions;

- most sports terms of a foreign language origin, need to be replaced by similar names of realities known to each person, for example: huma 'flat-rate depreciation', drakon 'quan-shu style', etc .;

- sometimes complex, long on demand terms or the absence of such ones give rise to the emergence of new ones: banka, baraban 'subbench', bichky 'throws with appropriate grip of hand and back', etc .;

- from the media (in particular, sports programs, newspapers, magazines).

As the research shows, the life of sports jargon also depends on the sphere of communication - family or extra-family sphere.

Within the family, respondents hardly use sports jargon. However, if there are several children in the family, they may use pupil, student, youth, sports and other types of jargon, depending on their age, and may be imposed by their own family micro-jargon.
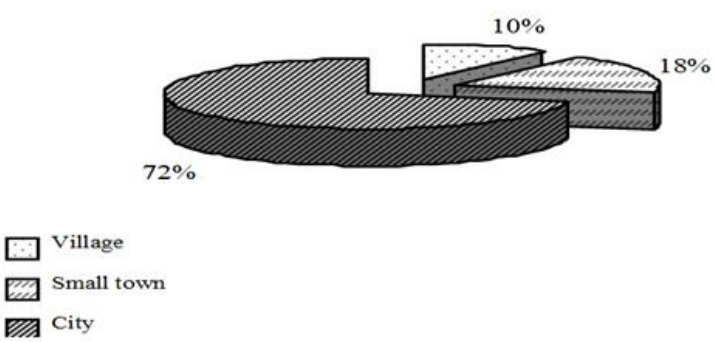

Pictures 1. Spread of jargon in different residential places

3 Ханин Ю.Л. Психология общения в спорте. Москва : Физкультура и спорт, 1980. C. 63. 


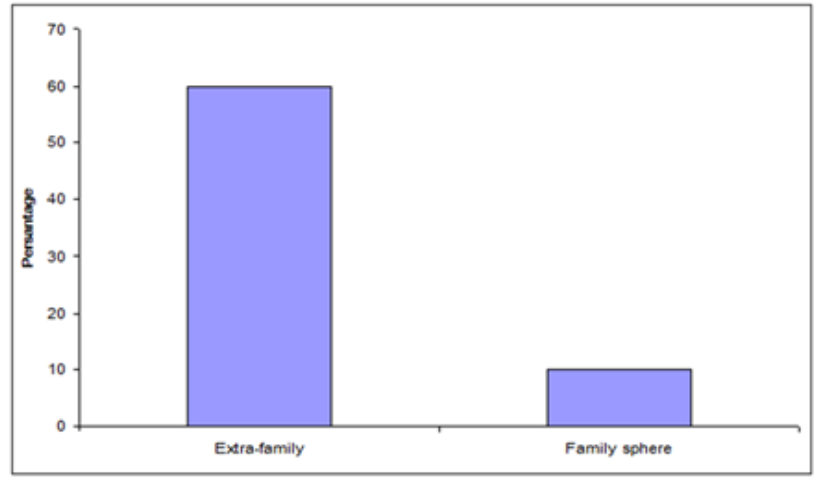

Picture 2

Comparing the frequency of the use of jargon units in the family and extra-family spheres of communication, we note that it is naturally lower in the family sphere than in the extra-family (picture 2). First of all, this is conditioned by the situation of communication and the social role that the speaker performs at the moment of speaking.

It is known that "every person constantly expresses what he thinks is the most appropriate, rational, possible in a specific situational-communicative case $<\ldots>$... Extra-family sphere enables the communicator to use different speech means.

We consider the need to address another factor that sig nificantly affects the frequency of use-functioning of jargon phenomena in the language and prevalence depending on the type of settlement. Thus, in particular, the largest percentage of "users" of sports jargon reside in large cities (see picture 1).

This situation seems to be explained by the fact that it is in the cities, first, the highest concentration (number) of people involved in sports; secondly, it is in these cities that the largest number of sports facilities (sections, clubs, schools, etc.) are represented; and, thirdly, the big cities are, for the most part, the venue for various competitions, and therefore the place for the most intense communication of athletes. We have cursory observations on the similarity of processes at the level of "district centers sub-districts": the degree of jargon use is higher in towns with the status of a district center than towns without such status. However, we cannot speak about any other facts or signs yet - this needs research.

4 Лихачев Д.С. Арготические слова профессиональной речи. Развитие грамматики и лексики современного русского языка. Москва, 1964. С. 320. 
There is no doubt that the majority of jargon has one direction of distribution: city $\rightarrow$ town / village. In our opinion, we need to take into account some particular feature of jargon propagation: they rarely appear and spread rapidly among the local, rural youth who use them according to their needs.

One of the sources of replenishment of jargon may be the addition of terms, which in turn become a mediator in the development of unfamiliar (difficult to pronounce, unusual for hearing, sometimes incomprehensible) terminology. In this case, the jargon is a mediator between the unfamiliar and its own.

According to L. Stavytska, the testimony of openness of every social intellect is the fact that "certain professional jargon is used not only by representatives of a certain profession, but also by people who are unprofessionally engaged in a certain type of activity (computer specialists and computer users, sportsmen and musicians) as well as sports fans). Therefore, the boundaries of professional jargon are quite blurred, and such units, as noted, easily become the property of the YS"(youth jargon, jargon deciphering ours - L.K. $)^{5}$.

However, the core group of sports jargon is the prerogative of the athletes themselves, who create peculiar language models. In addition, it can be argued that sports jargon is primarily a sign of group membership. To see this, they tried to schematically divide kinds of sport into individual and team (group).

Table 3

\begin{tabular}{|c|c|c|c|}
\hline Individual & Total-group & $\begin{array}{l}\text { Synchronous- } \\
\text { group }\end{array}$ & $\begin{array}{c}\text { Functional- } \\
\text { group }\end{array}$ \\
\hline $\begin{array}{l}\text { - athletics } \\
\text { - weightlifting } \\
\text { - figure skating } \\
\text { - running } \\
\text { disciplines } \\
\text { - athletics } \\
\text { - swimming } \\
\text { - boxing } \\
\text { - wrestling }\end{array}$ & $\begin{array}{l}\text { - pentathlon } \\
\text { - sports } \\
\text { gy mnastics } \\
\text { - relays in } \\
\text { athletic running } \\
\text { and cross-country } \\
\text { skiing }\end{array}$ & $\begin{array}{l}\text { - bobsleighs } \\
\text { - rowing (team } \\
\text { boats) }\end{array}$ & $\begin{array}{l}\text { - football } \\
\text { - volleyball } \\
\text { - basketball } \\
\text { - hockey } \\
\text { - handball } \\
\text { - cycling (group } \\
\text { races) } \\
\text { - rugby and so } \\
\text { on }\end{array}$ \\
\hline
\end{tabular}

Sports games can be considered as purely team ones: football, volleyball, handball, basketball, hockey, rugby, etc. According to our calculations, the football players' jargon is mostly used. Football is one of the most

5 Стойков С. Социальные диалекты (на материале болгарского языка). Bonp. языкознания. 1957. № 1. С. 78. 
entertaining sports that attracts the attention of people of different generations and social groups. Because of this, most football jargons are primarily open to the public and only a small number is served directly to players during the game.

Sports jargonims appear mostly in the environment of sportsmen, commentators, amateurs, fans. There are several reasons for this:

1. Sports terminology is quite difficult to pronounce (a significant number of such names of foreign origin), so users for convenience, accessibility change some names or completely replace with others. This is especially true of titles that refer to types of oriental martial arts, other sports that are new to Ukrainians. For example, in aerobics 'roztyazhka' is used instead of stretching, in karate - to 'murashky' instead of mawashi-tsuki, etc. (imaginary cannot be drawn).

2. The speed of game situations, the need to exchange information directly in the course of performing quite complex collective actions, which in turn require considerable effort and often involve high emotional tension, force players to use a language technique, the essence of which is to replace the official common name, which for various reasons does not meet the immediate needs of playing activity and gaming communication, more convenient, appropriate and, for the most part, more concise. For example, volleyball players use the words 'prostril', 'pivnisika' when surving the ball, they call combinations 'khrest', 'napruzhena' and the like.

3. Equally important is the fact that such verbal signs can be easily replaced with non-verbal ones (facial expressions, gesture, movement, body position), which in turn facilitates communication (in particular, increases the speed of passing-acquiring information response to it).

The analysis of the material showed that the conscious use of sports jargon is caused by a certain set of factors: territorial dependence, age of the communicant, his level of education, communication situation, topic of conversation and even a specific type or stage of sports activity (training, direct participation in competitions, post-game activities).

It is worth mentioning quite interesting observations about the names of the team sports (volleyball, basketball, handball). To achieve positive results, players sometimes use a secret (unintelligible opponent) language, code, during the game. For example, during a competition, the basketball team, before entering the ground, agrees to replace the usual words with the designation of common actions "by their own", so that the opponents do not know their strategy and tactics. So, when playing standard situations (throwing the ball through a certain line, playing the ball, after punching free throws) athletes use the words 'giving the ball' 'triple', 'jersey', 'beat in the left corner of the field' etc. For the most part, the whole team is instructed by the coach, and the player under the first number (this must be a smart 
person) controls the process. Sometimes it is a group rather than a collective agreement: the two players agree on one or the other "terminology". It is worth noting that in each specific game athletes are differently called common sports concepts, replacing sports terms with specific ones, which helps to mislead the opponent and ultimately has a significant effect on the positive result of the matches. Therefore, not only training and other qualities of athletes, but also language (namely its constituent jargons) are also decisive in achieving the desired results in "non-linguistic" activity. It should be noted that the masking (concealing) elements of the old argosystems and sports jargon differ significantly: in sports jargon, such names are "butterflies", intended for single use (one to two games) and devoid of reproducibility.

\section{Nominal-thematic groups of sports jargon}

In a thematic group, words are related not to language but to nonlinguistic means, because of the realities expressed in them on the basis of intralingual factors. In modern linguistics, thematic analysis of words is considered to bee one of the most common, and also it is a standard method of learning nouns.

We distinguish all sports jargon names into two broad groups - common names and proper names. Each of these groups has its own subgroups and corresponding microgroups. The interpretation of the jargon content is based on the responses of our recipients, while taking into account possible interpretations (respectively, multiple motivation) and phenomena of socalled folk etymology, different pronunciation, etc. In addition, we also include in the analysis borrowed from other jargons, from other levels of the national language, the names which in the sports jargon in their semantics have the element "sports" (for example, chaynyk in the inter-jargon is a beginner in something, stupid; in sports jargon - a fumbler athlete that doesn't work).

For example, in the group "common names" we give different names that denote such realities as the names of people whose activities are related to certain sports. The basis of jargon sports names of people is based on various motivational features: kinds of sport: probitiy 'a person who is involved in boxing for a long time'; horbatiy 'an athlete engaged in sports tourism'; 'disc throwers' skorpion; parapent'or 'paraglider'; strausy 'athletes engaged in speleotourism'; pikhota 'hiking'; nimfi 'athletes who do gymnastics on water'; kachky 'athletes engaged in weightlifting' or ' amateurs who take up bodybuilding'; husar 'a person involved in equestrian sports and has achieved some success'; lodorubi, sokirnyky 'mountaineers'; the place and role of the athlete in the team: nos 'a defender playing against center'; kum 'a partner on a glider'; lehioner 'a player in a team of foreign 
countries'; opikun 'an athlete who is attached to one of the best players of the opposing team and tries to counteract certain actions'; vusyk 'a back-line player who occupies the place of the third 'mustache' of the lane area'; zapaska 'a spare player'; taran 'ka 'an attacker who successfully punches (ram) 'wall'; osnovka 'main team'; ekskursant, turyst 'a player who often sits on the subbench'.

The specificity of the semantic structure of the jargon sports units leads to the creation of a large micro-group of names in terms of skills and characteristic actions: konik-horbunok 'athlete engaged in diving; pidnosnyk postachal'nyk 'a footballer who successfully passes the ball to another player'; khirurh 'a player who is quite cruel on the playing field'; pizhon 'a player who often puts the airs'; profesor 'an experienced player'; pushka 'a player with an accurate and powerful punch, almost always hits the target'; tantsyuryst, dirka 'goalkeeper who often misses goals'; sylach 'the one who can hold the bar for a long time'; syla of 'athlete who fulfilled the requirements to become the Master of Sports'; pidzhak 'athlete who did not show positive results during the competition'; ikhtiandr 'a confident swimmer who wins'; elektrychka 'a player who moves very fast on the field'; tekhnar is a 'technical boxer who loves to play with an opponent'. Individuals for specific actions during the competition: lyzun 'athlete catching up with his rival on the treadmill'; dubler 'an athlete who scored several goals in the opponent's goal in one match'.

Considering that one of the defining features of athletes is their physical qualities, a noticeable and significant micro-group of jargon has been formed in terms of physical qualities and external features: dokhodyaha 'skinny, tall athlete who has not achieved significant success in sports'; mashyna 'a strong athlete'; kryuchok 'so-called athlete who slams during a certain exercise'; herkules 'lightweight fighter'; there is also a small amount of jargon by age category: kadet 'athlete under 16'; zelenyy 'person who has recently started doing sports'; muzhyk 'athlete over 21 ' and using chemicals: farmatseft 'athlete using chemicals'.

The second large subgroup of sports jargon denotes actions, processes, and phenomena: tormozun 'wet snow on the ski lane that slows down does not allow it to move quickly'; tempar 'fast running in a certain distance'; sukhar 'lack of goals in the match, neither team scored in the opponent's goal'; anulyak 'revocation of a judge's decision' osobnyak 'personal competition score'; dohorimyak 'a play and results stipulated by both teams beforehead' arrangement; bichnyak 'a lateral throw'; svizhak 'snow that just fell on the ski slope; buratinchyky 'running on straight legs (without bending them)'; eks trem 'extreme loads'; baranka 'zero score; zabaranyty 'do not do any attempts in pole vaulting'; promazaty 'to pass by the right landmarks, didn't hit the target'; zatsentruvaty 'to get to the center'; bychky (judo) 'throws with appropriate grip 
of hand and back'; vislyukovi pidyomy 'partner's lifts'; den ' a viatsiyi 'reaction to a football feint'; verkhovaduel 'head game'; prostril 'passing the ball at the bottom, along the goal' and more.

A large group consists of sports jargon for the designation of sports exercises and styles: straus, roztyazhka 'an exercise during which certain muscles stretch'; skladka 'exercise for developing flexibility'; pivsvichka 'an exercise during which, while lying on the back, the person slowly raises straightened legs and then hips'; pluh 'exercise of lying on the back, arms along the torso, without bending then lift legs and bring them over the head'; praporets ' the 'optional exercise with flags' checkbox; stil'chyk 'exercises for hip muscles, romashka 'exercise on flexibility'; pistolet 'an abdominal muscle exercise'.

It is interesting in view of the motivational traits underlying the names, there is a subgroup of the names of the sports equipment, its features: bayda 'canoe'; var 'varnometer'; anatomichka 'anthropometric backpack'; klyuv 'curve arrow'; lysyy 'without upper mast'; prezervatyv 'aqualung'; ryumka a 'basketball ring on a stand' kolobok 'round shaped backpack'; zabory 'barriers through which athletes overcome obstacles'; truba 'very thick arrow'.

Among the common names there is a subgroup of sports facilities, venues for sports activities: plyuvalka 'shooting range with primitive equipment'; kachalka 'gym where bodybuilders train'; lahuna 'large size pool with unchlorinated water'; koryto 'small in size pool'; zhabnyk 'small size swimming pool for children'; korobka 'football or hockey field'; nytky 'in tourism, route lines, their length'; kachka 'bodybuilding gym'.

Names of medicines: anabol 'anabolic steroids'; moroz 'painkillers'; oliya 'anabolic steroid based on oil'; to action: palyvo 'anti-doping control'.

Names of parts of the body mainly by their features: kolotukhy 'legs'; halife 'big thigh'; khobot athlete's 'build up neck' trunk; banky 'build up biceps (round, solid)'; shchichky 'inner part of foot'.

There is also a small amount of jargon to indicate sports wear, equipment, awards: spidnytsya 'piece of canoeing equipment for sealing a boat'; utyuhy 'tense knee socks at footballers'; kupasyk 'swimsuit'; zebra 'judge clothing' and others.

The analysis of the present material also confirms the presence of sports jargon - proper names. They make up a large group of nominally thematic group. These are, in particular, anthroponyms, among which the largest subgroup is nicknames. We believe that this fact is not accidental, because they are often used by the athletes, fans, coaches and others.

Athletes' nicknames are extremely common. Very often, some athletes are better known by their nicknames, not by their names. Even the media often use nicknames. 
The appearance of anthroponymic jargon is influenced by various factors. The most common features for the name are:

- physical features: Iron Fist 'nickname of Vitali Klitschko'; Iron 'Mike Tyson's nickname'; Shark 'Denis Selantiev's nickname' and the like;

- certain event in human life and action: Three Heads 'boxer Lewis's nickname'; Otorvinos 'Michael Tyson' etc.;

- surnames: Loban 'head coach V. Lobanovsky'; Dema 'football player Andrey Demchenko'; Khmel' 'footballer V. Khmelnitsky'; Blokha 'footballer, former coach of the national team of Ukraine Oleg Blokhin';

- preference: Varenik 'a person who loves to eat dumplings'; Krolik 'favorite swimming style is crawl' Ryba 'a person who is very fond of fishing' and the like;

- features of speech: Sheptun 'a person who whisps; some of the recorded jargons are units that indicate the unofficial names of the clubs, the names of which are based on various features:

- team name: Dynamik 'Dynamo'; Torpedon 'Torpedo'; Metal 'Metalurh'; Loco 'Locomotive'; Shakhta 'Shakhtar', Metalobrukht 'Metalist', etc .;

- name of the city, territory: L'vy 'Carpathians' (Lviv); Kup'yany 'Lokomotiv' (Kupyansk), etc .;

- team membership in a specific organization, structure: parovozy 'Locomotive'; menty 'Dynamo'; narodnyky, torhashi 'Spartacus'; hirnyky 'Shakhtar' and others;

- clothing color: Pomaranchevi 'Ajax' (Holland); Chervono-bili (Denmark national football team);

- name of items, animals: Kanoniry 'Arsenal'; kroty 'Shakhtar' and others.

A separate group of sports jargon is the jargon of fans. As T.Yeschenko notes, the jargon of sports fans is an integral part of the youth jargon and is distinguished against the background of the thematic orientation of the word semantics into the sports sphere. Its keywords include sports attribute names (mash-ups, caps, badges, t-shirts, flags), connotative proper names (players' names and team names), etc ${ }^{6}$.

We will not go into detail in the analysis of the fans' jargon, this phenomenon is unsuccessfully sought to be explored in T. Eshchenko's scientific research. It should be noted that most of the words recorde $d$ by the author are youth jargon: lokhovoz 'bus', kolesa 'any car', kovbasa 'double bus "Icarus", babul'ky 'money', snikers 'vodka' and others. Among the variety, the author also presents purely "fan" jargon: rozetka 'kashne', fanzin

6 Єщенко Т. Український жаргон спортивних уболівальників Лінгвістичні студії : Зб. наук. праць. Вип. 13. Донецьк : ДонНУ. С. 251. 
(fenzin) 'fan print magazine', fayer 'torch, firecrackers that fans light on the terrace', hanchirky of 'enemy club muffler' shyzivka 'team fight song', etc. It can be noted that T. Eshchenko's research is one of the first attempts in Ukrainian linguistics to systematize the names of particular jargon - sports fans (fans).

So, analyzing the nominally-themed groups of sports jargon, we note that almost all important events for an athlete are indicated by jargon. Compared to the established sports nomens, sports jargons are noticeably widespread among users, because they help to detail, specify, clarify, certain sports phenomena.

In view of the above, we can conclude that the formation of the jargon thematic group "sports-game nomenclature" reflects the general current state of the Ukrainian sports term system - an organic nominative subsystem of the Ukrainian language, subject to the general laws of its development - on the one hand, and on the other is a much wider group of names than codified nomens.

\section{CONCLUSIONS}

The study of sports jargon as a holistic phenomenon in the Ukrainian language has led to some general conclusions.

1. To find out the reasons for the appearance of jargonims, their distribution and use, we conducted a number of observations, surveys, etc. As a result, we found that the main reasons for the emergence and spread of sports jargon are:

- incompleteness of the codified system of sports nomenclature and efforts to supplement it;

- convenience, ease, naturalness in the use of jargon compared to codified ones (especially with nomens of foreign origin) and an effort to make common sense to specific conditions of existence;

- the use of jargon as a means of self-identification in a sports society, as an indication of belonging to such a society.

2. Our research has shown that the extent to which sports jargon is distributed and how it is used depends on certain determinants: the age of the speaker, the level of education, the family / extra-family sphere, the territorial factor, even the sport - group or individual, the possibility / inability to use non-verbal means of communication.

3. The systematization and analysis of nominally-thematic groups in sports jargon testify to a number of features, trends both in all Ukrainian sports nomenclature and in jargon in particular.

\section{SUMMARY}

The study of sports jargon, its functions in language, gives the opportunity to determine the place of individual jargon in the common- 
language space of the Ukrainian language and, accordingly, to establish the general patterns and basic tendencies of existence and functioning of jargon as a linguosocial phenomenon. As a result of our research, we identified the main causes for the emergence and spread of sports jargon: the inability to meet all the needs of sports-athletes through a codified system of sports nomenclature; convenience, ease, naturalness in the use of sports jargon compared to codified (especially borrowed from other languages); efforts to bring existing common units to specific communication conditions; the ability to self-identify through sports jargon. The prevalence of sports jargon is influenced by factors such as the age of the speaker, the level of education, the type of sports activity (group or individual, women's sports or men's), the media, etc. Due to its peculiarities, the sports jargon expresses a rather significant feature that distinguishes it fromother jargons: at its core it is not a contraposition of literary language and its styles (as jargon is traditionally viewed in linguistics), but rather a powerful complementary, concrete and detailed one. Sports jargon, compared to sports codified nomenclature, is characterized by a greater variety of units. This, in turn, can be explained by two interrelated reasons: the relevance of a codified nomenclature to a significant number of referees and, accordingly, the lack of names to indicate them, on the one hand, and the importance of such referees to the athlete in a particular communication situation, type of activity and appropriate effort to indicate such referents, on the other. The motives for such a name can be sports activities, processes and phenomena, exercises, styles and actions, individual characteristics and achievements of the athlete or the whole group, sportsmen's names and official club names, etc. Bas ed on the analysis of thematic groups, it is possible to state that there is a clearly expressed sport-centricity in nominative processes.

Equal to sports nominative-thematic groups in the literary language, nominally-themed sports-jargon groups have their own peculiarities and specific features:

- sports jargon is an organic and natural part of the system of names of the Ukrainian national language, which is created and developed according to the general rules of the Ukrainian language;

- the degree of nominally-thematic diversity in sports jargon is much higher, which in turn is a consequence of the efforts of athletes to name all the realities of significance for them, which in one way or another affect the state of worldview; that is why the jargon, which motivates the evaluation aspect, is quite noticeable;

- various (sometimes unexpected) realities and attributes may occur before the jargon appears: type and kind of sports activity, processes and phenomena, exercises and styles, inventory, equipment and clothing, individual characteristics of the athlete, objects or actions, sportsmen's 
names and official proper names of clubs, establishments, facilities and more.

This may indicate one significant difference between sports jargon and other jargons of the Ukrainian language: sports jargon is not a juxtaposition of literary language and its styles, but a powerful means that complement, concretize and detalize, sometimes even substitute.

\section{REFERENCES}

1. Єщенко T. Український жаргон спортивних уболівальників. Лінгвістичні студї : Зб. наук. праць. Вип. 13. Донецьк : ДонНУ. C. 250-255.

2. Карпець Л.А. Український спортивний жаргон: структурносемантичний аспект : автореф. дис. ... канд. філол. наук : 10.02.01. Харків, 2006. $19 \mathrm{c}$.

3. Лихачев Д.С. Арготические слова профессиональной речи. Развитие грамматики и лексики современного русского языка. Москва, 1964. C. 311-359.

4. Ставицька Л. Функціонування жаргонної лексики в сучасній українській усно-розмовній мові. Вісник Харківського університету. Вип. 491. Серія «Філологія». Харків : ХНУ, 2000. С. 294-297.

5. Стойков С. Социальные диалекты (на материале болгарского языка) Вопр. языкознания. 1957. № 1. С. 78-84.

6. Ханин Ю.Л. Психология общения в спорте. Москва : Физкультура и спорт, 1980. 208 с.

\section{Information about the authors:} Karpets L. A.,

Doctor of Philosophy, Professor, Head of the Department of Ukrainian and Foreign Languages Kharkiv State Academy of Physical Culture 99, Klochkovska Str., Kharkiv, 61000, Ukraine

\section{Kovalenko J. N.,}

Senior Lecturer of the Department of Ukrainian and Foreign Languages

Kharkiv State Academy of Physical Culture 99, Klochkovska Str., Kharkiv, 61000, Ukraine 